\section{Adventitious Root Formation and Development in Cuttings of Mussaenda erythrophylla L. Schum. \& Thonn.}

\author{
Rolston St. Hilaire ${ }^{1}$, Carlos A. Fierro Berwart ${ }^{2}$, and \\ Carlos A. Pérez-Muñoz \\ University of Puerto Rico, Mayagüez Campus, Mayagüez, PR 00681
}

Additional index words. indole butyric acid, plant anatomy, vegetative propagation

\begin{abstract}
Mussaendas (Mussaenda spp.) are ornamental shrubs, and some cultivars are difficult to root. This study was conducted to explore how adventitious roots initiate and develop in the cultivar Rosea and to determine if anatomical events are associated with difficulty in rooting stem cuttings. Stem cuttings were treated with $5,10,15 \mathrm{mmol} I B A$, or distilled water, and sampled every 2 days over 26 days to observe adventitious root formation and development. Adventitious roots initiated from phloem parenchyma cells. Cuttings treated with $15 \mathrm{mmol}$ IBA had a mean of 18 root primordia per basal $1 \mathrm{~cm}$ of cutting after 10 days. Primordia were absent in nontreated cuttings at 10 days. These results suggest that nontreated cuttings are difficult to root because few primordia are produced. Chemical name used: $1 H$-indole-3-butyric acid (IBA).
\end{abstract}

Mussaendas (Mussaenda spp.) are ornamental shrubs valued for their enlarged, colorful bracts (Jayaweera, 1963; Rosario et al., 1990). They are native to the Pacific Islands, Asia, and the tropics of Africa (Jayaweera, 1963), and are the most widely accepted ornamental plants of the Philippines (Rosario, 1987). Heterostyly, low pollen fertility (Rosario etal., 1990), and poor fruit production (Rosario, 1987) limit seed production. Therefore, most mussaendas are propagated by layering or stem cuttings (Kumar and Vijayakumar, 1984; Rosario, 1987), although some cultivars of potential ornamental importance are difficult to propagate by stem cuttings (Bose et al., 1975; Kumar and Vijayakumar, 1984). Knowledge of anatomical events associated with root formation and development in the species would be useful because it may permit development of improved rooting procedures.

Information is sparse about the internal changes in stem structure that lead to root formation in mussaenda. Esau (1960), Girouard (1967a, 1967b), and Hartmann et al. (1990) have shown that the cellular origin of adventitious roots in higher plants depends on the type of tissue and the species. Davies et al. (1982) established that IBA affects root development but does not change the origin of root primordia in Ficus pumila L. To our knowledge,

Received for publication 5 Sept. 1995. Accepted for publication 28 June 1996. This paper is a portion of a thesis submitted by R.S.H. in partial fulfillment of the MS requirements at the Univ. of Puerto Rico. This research was supported in part by the Caribbean Scholarship Program and the Univ. of Puerto Rico. The cost of publishing this paper was defrayed in part by the payment of page charges. Under postal regulations, this paper therefore must be hereby marked advertisement solely to indicate this fact.

${ }^{1}$ Department of Horticulture. Current address: Dept. of Horticulture, Iowa State Univ., Ames, IA 500111100 .

${ }^{2}$ Department of Horticulture.

${ }^{3}$ Department of Biology. nothing is known about the effect of IBA on adventitious root development in stem cuttings of mussaenda.

In this study, we used $M$. erythrophylla 'Rosea' because preliminary experiments conducted in Dec. 1993 showed that this cultivar was particularly difficult to root. Our objectives were to study how adventitious roots in the species initiate and develop and to determine if anatomical events are associated with recalcitrant rooting.

\section{Materials and Methods}

Plant material. Shoots 6 to $7 \mathrm{~mm}$ in diameter and $15 \mathrm{~cm}$ long were selected randomly from a field-grown clonal plant of $M$. erythrophylla 'Rosea' at the Univ. of Puerto Rico, Mayagüez (lat. $18^{\circ} 12^{\prime} \mathrm{N}$, long. $67^{\circ} 8^{\prime} \mathrm{W}$ ). The stock plant was 6 years old and was fertilized every 3 to 4 weeks with $56 \mathrm{~g}$ of $10 \mathrm{~N}-$ 4.3P-8.3K (Green Crop; Ochoa Fertilizers, Cataño, P.R.). Cuttings had two or three nodes and were taken from the terminal and middle shoot positions because preliminary experiments showed that the position from which cuttings are taken did not affect rooting. The lower two leaves and two-thirds of the lamina of the remaining leaves were removed to reduce transpiration, but adequate leaf photosynthetic area was retained. The proximal cutting ends were dipped to a depth of $2 \mathrm{~cm}$ for $10 \mathrm{~s}$ into 0 (distilled water), 5,10 , or $15 \mathrm{mmol}$ IBA dissolved in $\mathrm{NaOH}$ at $0.1 \mathrm{~mol} \cdot \mathrm{L}^{-1}$. The basal $5 \mathrm{~cm}$ of the stem was inserted in perlite in a $60 \times 44 \times 15$-cm propagation trough. The design was a completely randomized block with four IBA treatments and 39 blocks. There were three cuttings per block.

Environmental conditions. The propagation trough was enclosed in a 0.15 -mm-thick clear polyethylene tunnel to maintain humidity. Cuttings were misted $15 \mathrm{~s}$ per minute from 0600 to 1800 HR. The experiment was conducted in an open-ended Quonset greenhouse with air within the tunnel kept at $29 \pm 7{ }^{\circ} \mathrm{C}$ during the day and $20 \pm 2{ }^{\circ} \mathrm{C}$ at night. Photosynthetically active radiation measured at midday at the cutting canopy was $438 \pm 178$ $\mu \mathrm{mol} \cdot \mathrm{m}^{-2} \cdot \mathrm{s}^{-1}$ (quantum sensor; LI-COR, Lincoln, Neb.) during the experiment. A LI-COR 1000 datalogger was used to record and store radiation and temperature data.

Sampling and histological procedures. Three cuttings were selected at random for harvest before placement in the medium (day 0 ). Four blocks (12 cuttings) were harvested randomly every 2 days between 0700 and 1000 HR for 26 days. All cuttings collected before root emergence were processed for histology to assess developmental changes during root formation. The basal $1 \mathrm{~cm}$ of each cutting was cut and divided into disks $2 \mathrm{~mm}$ thick. Disks were fixed in formalin-acetic acid-ethanol (Berlyn and Miksche, 1976) for $24 \mathrm{~h}$. Fixed sections were softened in $30 \%$ hydrofluoric acid for $72 \mathrm{~h}$ and washed in flowing tap water for $48 \mathrm{~h}$ to remove the acid (Brooks et al., 1966). Sections were dehydrated in an ethanol-tertiary butyl alcohol series and embedded in Paraplast-xtra (Oxford Labware, St. Louis). Serial transverse sections were cut at $14 \mu \mathrm{m}$. Sections were stained with safranin-fast green (Berlyn and Miksche, 1976).

Data collection and analysis. Slides were observed and photographed through a Nikon Optiphot microscope fitted with a Nikon FX35A camera (Nikon, New York) and a calibrated ocular micrometer. Root primordia were counted and measured from their origin in the basal cambial region to their apex. Adventitious roots were counted and measured. Data were analyzed as a completely randomized block with treatment $\times$ block (day) used as experimental error. The linear relationship of root count and root length with time for each IBA concentration and the comparison of the number of root primordia produced were analyzed by using General Linear Model procedures of SAS (SAS Institute, 1989).

\section{Results}

Processed cutting sections collected before placement in the rooting medium revealed pith consisting of parenchyma cells and xylem that consisted of parenchyma cells and vessel elements (Fig. 1A). At 2 days, anatomy was similar to that on day 0 . Xylem was separated from phloem by a vascular cambium three to four cells thick (Fig. 1B). Phloem fibers were present between the phloem and cortex (Fig. 1B). A uniseriate epidermis that contained many trichomes was present (Fig. 1B).

At 4 days, meristematic activity was detected in phloem parenchyma cells. There was some variation in the developmental stage of cuttings within the same treatment, but at 6 days, root primordia were present in cuttings treated with 15 mmol IBA. At 8 days, all cuttings treated with IBA had root primordia (Table 1). By day 10, adventitious roots with clear vascular connections were present in all treated cuttings (Fig. 1C), but callus protruded 


\section{Propagation \& Tissue Culture}

from the basal ends and sides of the nontreated cuttings (Fig. 1D). Callus did not form on treated cuttings.

Fewer adventitious roots formed in nontreated cuttings than in IBA-treated cuttings (Fig. 2), and the number of roots increased with increasing IBA concentration (Fig. 2). Adventitious root length was not affected by IBA (data not shown).

\section{Discussion}

This study shows that IBA treatments stimulate root initiation in M. erythrophylla 'Rosea'. Meristematic activity in phloem parenchyma cells preceded the formation of adventitious roots. At day 10, no root primordia had been initiated in nontreated cuttings (Table 1).

Phloem parenchyma cells adjacent to the vascular cambium divided and produced adventitious roots. These results indicate that phloem parenchyma cells in 'Rosea' are able to dedifferentiate and become meristematic. This observation is consistent with previous studies (Davies et al., 1982; Girouard, 1967b; Harbage et al., 1993; Lovell and White, 1986).

Meristematic activity probably was not detected before 4 days because thick $(14 \mu \mathrm{m})$ sections were used to obtain satisfactory wax ribbons. With 11- $\mu$ m-thick, wax-embedded sections, Apter et al. (1993) detected no meristematic activity in conventionally propagated and tissue-cultured cuttings of Asian jasmine [Trachelospermum asiaticum (Siebold \& Zucc.) Nakai] after 3 days of root induction.

Two days were required to observe development of root primordia after the lag phase in M. erythrophylla 'Rosea' treated with $15 \mathrm{mmol}$ IBA, which demonstrates that primordia develop rapidly once cell division is initiated.

At 6 days, root primordia were present in cuttings treated with 15 mmol IBA, suggesting that this treatment accelerated primordia formation. At 8 days, all cuttings treated with IBA had primordia that emerged through the phloem fibers by day 10 . By day 10 , root primordia were absent in nontreated cuttings, which may explain why nontreated cuttings are difficult to root.

Basal callus present in nontreated cuttings after 10 days produced adventitious roots by day 30 , so adventitious roots are also capable of originating from callus tissue. Nontreated cuttings were not sectioned after 10 days, so the origin of roots produced from callus was unclear. But Blakesley et al. (1991) reported that root primordia can be initiated within callus tissue; therefore, these may be classified as adventitious roots.

This study showed that anatomical events are responsible for the difficulty in rooting nontreated cuttings of 'Rosea'. Overall root production is closely linked to the number of root primordia.

\section{Literature Cited}

Apter, R.C., E.L. Williams, and F.T. Davies, Jr. 1993. In vitro and ex vitro adventitious root formation in Asian Jasmine (Trachelospermum asiaticum). I. Comparative morphology. J. Amer. Soc. Hort. Sci. 118:902-905.
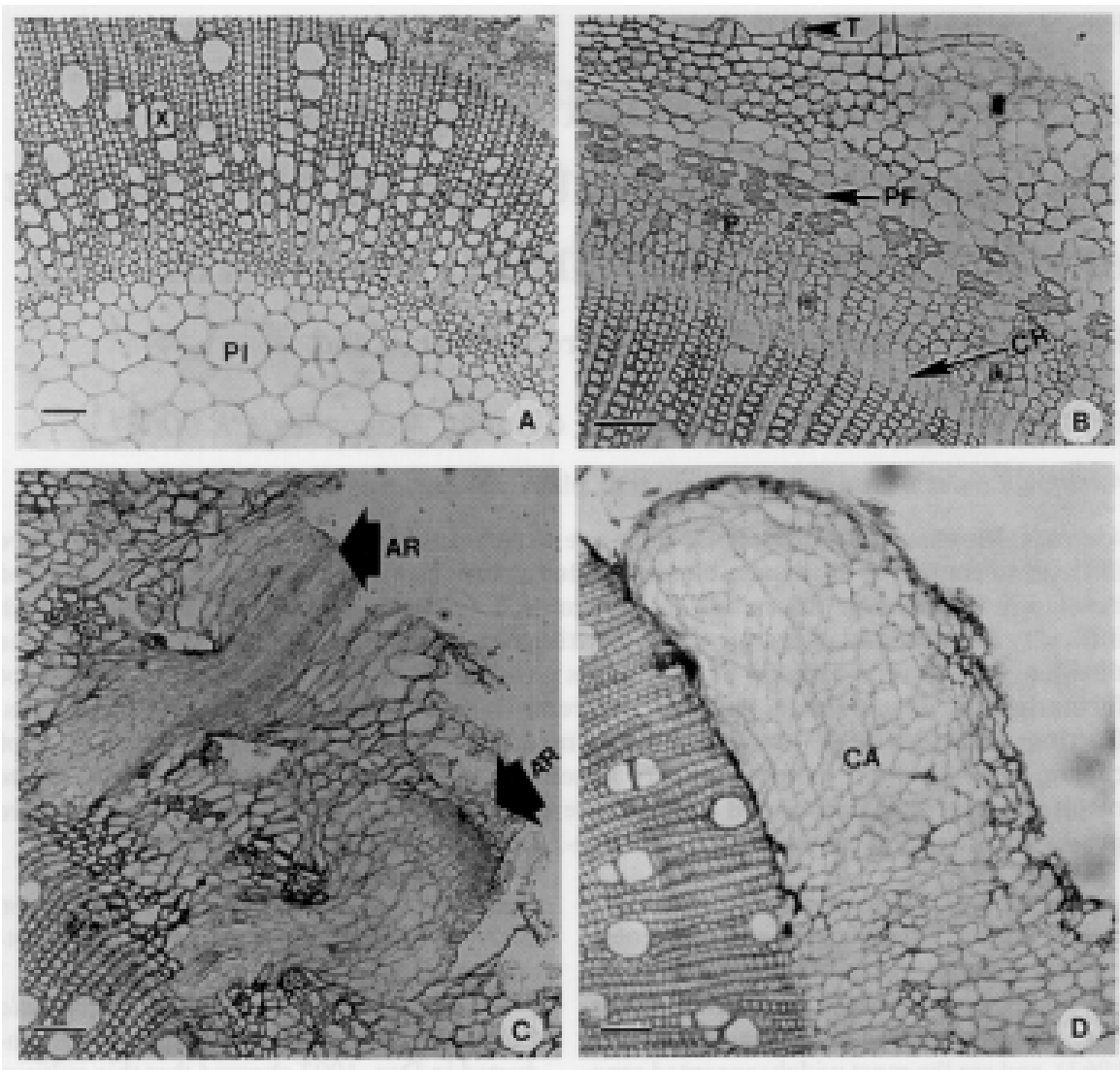

Fig. 1. Transverse stem sections of Mussaenda erythrophylla 'Rosea': (A) Day 0; bar $=20 \mu \mathrm{m}$. (B) Cutting treated with $5 \mathrm{mmol}$ IBA at 2 days; $b a r=20 \mu \mathrm{m}$. (C) Cutting treated with $10 \mathrm{mmol}$ IBA at 10 days; bar $=50 \mu \mathrm{m}$. (D) Callus in nontreated cuttings; $\mathrm{bar}=50 \mu \mathrm{m}$. AR = adventitious root; $\mathrm{CA}=$ callus; $\mathrm{CR}=$ cambial region; $\mathrm{P}=$ phloem; $\mathrm{PF}=$ phloem fiber; $\mathrm{PI}=$ pith; $\mathrm{T}=$ trichome; $\mathrm{X}=$ xylem .

Table 1. Number and length of root primordia produced in the basal $1 \mathrm{~cm}$ of stem cuttings of Mussaenda erythrophylla 'Rosea' treated with indole butyric acid (IBA). Values are means of three replicates.

\begin{tabular}{lccc}
\hline \hline Day & $\begin{array}{c}\text { IBA } \\
(\mathrm{mmol})\end{array}$ & $\begin{array}{c}\text { No. } \\
\text { primordia }\end{array}$ & $\begin{array}{c}\text { Length of } \\
\text { primordia }(\mu \mathrm{m})\end{array}$ \\
\hline 6 & 0 & $0 \pm 0$ & $0 \pm 0$ \\
& 5 & $0 \pm 0$ & $0 \pm 0$ \\
& 10 & $0 \pm 0$ & $0 \pm 0$ \\
8 & 15 & $12 \pm 2$ & $180 \pm 70$ \\
& 0 & $0 \pm 0$ & $0 \pm 0$ \\
& 5 & $1 \pm 2$ & $400 \pm 120$ \\
10 & 10 & $11 \pm 1$ & $250 \pm 100$ \\
& 15 & $3 \pm 1$ & $360 \pm 240$ \\
& 0 & $0 \pm 0$ & $0 \pm 0$ \\
Contrast & 5 & $12 \pm 4$ & $520 \pm 140$ \\
Day 10 vs. day 6-8 & 10 & $7 \pm 4$ & $380 \pm 250$ \\
0 mmol IBA vs. others & 15 & $18 \pm 2$ & $160 \pm 30$ \\
5 vs. 10-15 mmol IBA & & $* * *$ & $* *$ \\
10 vs. 15 mmol IBA & & $* * *$ & $* * *$ \\
\hline
\end{tabular}

Ns, *******Nonsignificant or significant at $P \leq 0.01$ or 0.001 .

Berlyn, G.P. and J.P. Miksche. 1976. Botanical microtechnique and cytochemistry. Iowa State Univ. Press, Ames.

Blakesley, D., G.D. Weston, and J.F. Hall. 1991. The role of endogenous auxin in root initiation. I. Evidence from studies on auxin application and analysis of endogenous levels. Plant Growth Regulat. 10:341-345.

Bose, T.K., T.P. Mukherjee, and T. Roy. 1975 Standardization of propagation from cuttings under mist. I. Effect of type of wood and size of cutting on root formation. Punjab Hort. J. 15:139143
Brooks, R.M., M.V. Bradley, and T.I. Anderson. 1966. Plant microtechnique manual. 5th. ed. Univ. of California, Davis.

Davies, F.T., Jr., J.E. Lazarte, and J.N. Joiner. 1982. Initiation and development of roots in juvenile and mature leaf bud cuttings of Ficus pumila L. Amer. J. Bot. 69:804-811.

Esau, K. 1960. Anatomy of seed plants. Wiley, New York.

Girouard, R.M. 1967a. Initiation and development of adventitious roots in stem cuttings of Hedera helix L. Anatomical studies of the juvenile growth phase. Can. J. Bot. 45:1877-1880. 

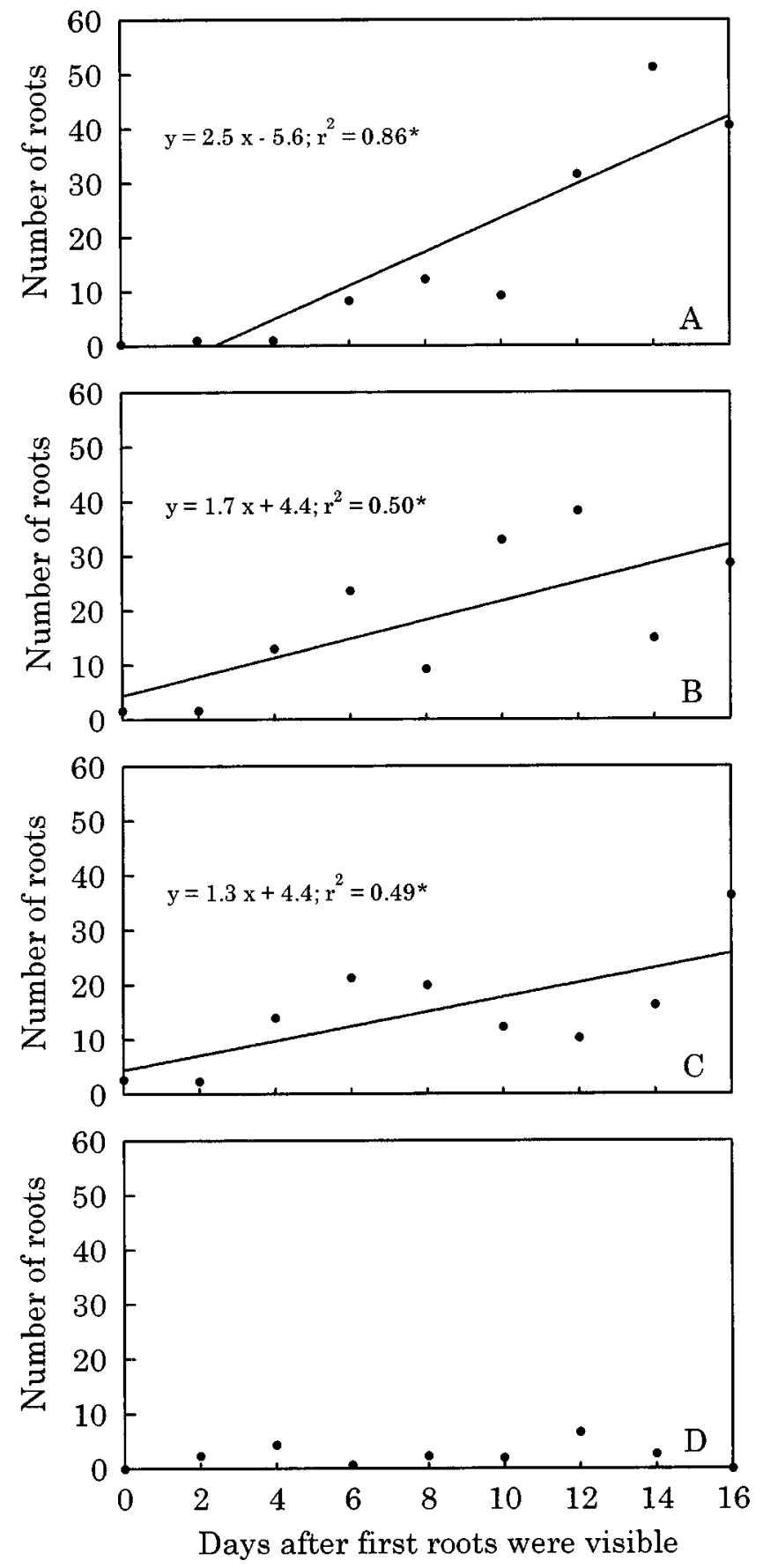

Fig. 2. Linear relationship of the number of roots with days after first roots were visible in Mussaenda erythrophylla 'Rosea' cuttings in response to (A) 15, (B) 10, (C) 5, and (D) 0 mmol of IBA. Each point is a mean of three replicates. "Significant at $P \leq 0.05$. Linear relationship of the number of roots with days after first roots were visible was nonsignificant for nontreated cuttings.
Girouard, R.M. 1967b. Initiation and development of adventitious roots in stem cuttings of Hedera helix $\mathrm{L}$. Anatomical studies of the mature growth phase. Can. J. Bot. 45:1883-1886.

Harbage, F.T., D.P. Stimart, and R.F. Evert. 1993. Anatomy of adventitious root formation in microcuttings of Malus domestica Borkh. 'Gala'. J. Amer. Soc. Hort. Sci. 118:680-688.

Hartmann, H.T., D.E. Kester, and F.T. Davies, Jr. 1990. Plant propagation principles and practices. 5th ed. Prentice Hall, Englewood Cliffs, N.J.

Jayaweera, D.M.A. 1963. The rubiaceous genus Mussaenda: The morphology of the Asiatic species. J. Arnold Arboretum 44:111-126.

Kumar, D.P. and N. Vijayakumar. 1984. Studies on the propagation of Mussaenda phillipica by stem cuttings. South Indian Hort. 32:373-374.

Lovell,P.H. and J. White. 1986. Anatomical changes during adventitious root formation, p. 111-140. In: M.B. Jackson (ed.). New root formation in plants and cuttings. Martinus Nijhoff, Dordrecht, The Netherlands.

Rosario, T.L. 1987. Mussaenda breeding in the Philippines, p. 190-199. In: W.N. Chang and R.T. Opeña (eds.). The breeding of horticultural crops. Food and Fertilizer Technol. Conf. for the Asian and Pacific Region, Taiwan.

Rosario, T.L., S.V. Siar, and F.B. Aurigue. 1990. Morphology and cytology of the progenies of an open pollinated Mussaenda 'Queen Sirikit'. Philippine Agr. 73:221-226.

SAS Institute. 1989. SAS/STAT user's guide, version 6. 4th ed. SAS Inst., Cary, N.C. 